\title{
Evaluation of Anticoagulant Proteins and Fibrinolytic System Markers in Children with Pneumonia
}

\author{
(1) Zahide Yalaki1', (D) Bülent Alioğlu², (1) Nurdan Çiftçi1, (D) Fatma İnci Arıkan¹ \\ 1Ankara Training and Research Hospital, Clinic of Paediatrics, Ankara, Turkey \\ ${ }^{2}$ Ankara Training and Research Hospital, Clinic of Paediatric Hematology, Ankara, Turkey
}

\begin{abstract}
Aim: Coagulation and fibrinolytic systems play an important role in the pathogenesis of complicated pneumonia. This study aims to evaluate and compare coagulation and fibrinolytic system markers and natural anticoagulant proteins with acute phase reactants, such as C-reactive protein or procalcitonin in children with pneumonia.

Materials and Methods: One hundred and fifteen patients and 87 healthy children were included in the study. Patients were separated into two groups based on viral and bacterial pneumonia diagnosis. Coagulation and anticoagulation system markers were compared with acute phase reactants in children with pneumonia.

Results: White blood cell numbers and D-dimer (DD) levels were higher in the pneumonia patients compared to the control group ( $p=0.001$ and 0.001 respectively). Protein $C$ activity and antithrombin activity in the patient group were significantly lower compared to the control group ( $p=0.001$ and $p=0.011$ respectively). Acute phase reactants and DD levels in the bacterial pneumonia patients were higher compared to the viral pneumonia patients $(p<0.05)$. Protein $S$ activity, fibrin monomers and fibrin degradation products were not significantly different between the bacterial and viral pneumonia patients. Protein $\mathrm{S}$ activity in the bacterial pneumonia patients was lower compared to the viral pneumonia patients $(\mathrm{p}=0.040)$. There was no difference in terms of antithrombin activity and protein C activity.

Conclusion: As a result, the relationships among acute phase proteins, anticoagulation proteins, and fibrinolytic system markers show that the coagulation and fibrinolytic system has an important role in pneumonia pathogenesis and associated inflammation. Evaluation of the coagulation system may help determine the severity of pneumonia in children and be used to monitor its clinical progress.
\end{abstract}

Keywords: Pneumonia, children, anticoagulant reactants, fibrinolytic system

\section{Introduction}

Pneumonia is an acute inflammation that develops in lung parenchyma as a result of changes in at least one of the lower respiratory defence mechanisms (1). More than 150 million children are diagnosed with pneumonia every year in developing countries. $23 \%$ of outpatient children and $29-38 \%$ of hospitalized children (33-50\% if younger than one) are diagnosed with pneumonia. 37\% of communityacquired pneumonia (CAP) occurs in children (2). In developed countries, the prevalence of CAP among children is 5 million cases per year, which creates a substantial demand for health services. The most common causative agents of CAP are Streptococcus pneumoniae, Haemophilus influenza, Mycoplasma pneumoniae, respiratory syncytial virus, rhinovirus, and parainfluenza viruses $(1,3,4)$.

\section{Address for Correspondence}

Zahide Yalaki MD, Ankara Training and Research Hospital, Clinic of Paediatrics, Ankara, Turkey Phone: +90 5064079866 E-mail:dr zahide@yahoo.com ORCID ID: orcid.org/0000-0002-3409-9016 Received: 03.02.2018 Accepted: 29.06.2018

${ }^{\circ}$ Copyright 2019 by Ege University Faculty of Medicine, Department of Pediatrics and Ege Children's Foundation The Journal of Pediatric Research, published by Galenos Publishing House. 
Coagulation and fibrinolytic system plays an important role in the pathogenesis of serious lung diseases such as complicated pneumonia and respiratory distress syndrome $(5,6)$. Activation of the coagulation system is triggered by endotoxin and other inflammatory mediators. As a reaction to these mediators, vascular congestion develops and alveoli are filled with fibrin during pneumonia. Fibrin residue products are secreted throughout the fibrinolytic enzyme degradation process by the fibrinolytic system. Heavy sepsis may cause disseminated intravascular coagulation (DIC) as a result of coagulation system activation through pulmonary inflammation in pneumonia. This may cause an increase in coagulation activation markers, D-dimer (DD), and fibrin degradation products (FDPs), and a decrease in natural anticoagulant proteins (5-8).

This study aims to evaluate and compare coagulation and fibrinolytic system markers and natural anticoagulant proteins with acute phase reactants, such as C-reactive protein (CRP), high-sensitive (hs)-CRP, and procalcitonin in children with CAP.

\section{Materials and Methods}

One hundred and fifteen patients and 87 healthy children (as the control group), between two months and 18 years of age, were included in the study. The study groups were selected from individuals who were admitted to the Ankara Training and Research Hospital Clinic of Paediatric and Paediatric Emergency. This study was obtained from the Ethics Committee of Ankara Training and Research Hospital with file (approval number: 0533 date: 10.01.2014). The parents of the study groups were given informed consent forms and written consent was obtained from the participants prior to the study.

Patients were divided into two groups based on viral and bacterial pneumonia diagnoses. Bacterial type pneumonia was defined based on at least two of the following three criteria: 1) plasma CRP level $>0.8 \mathrm{mg} / \mathrm{dL}, 2$ ) leukocyte number $>15 \times 10^{\circ} / \mathrm{L}$, and 3) alveolar infiltration in posterioranterior chest $\mathrm{x}$-ray. Patients who did not conform to these criteria were defined as viral pneumonia patients (1). Patients who started antibiotic treatment prior to the study, hematologic patients, and patients with a chronic illness were not included in the study.

Blood samples were taken from the patients before treatment. White blood cell (WBC) count, CRP, hs-CRP, procalcitonin, fibrinolytic system markers including $D D$, FDPs, fibrin monomers, and natural anticoagulant proteins such as protein $C$, protein $S$, and antithrombin III were investigated by means of the blood samples.

\section{Statistical Analysis}

The results were analysed using (SPSS Inc. Chicago, IL, USA) 16.0 statistical analysis package program. Chi-square test was used for qualitative variables in statistical comparisons. Normal distribution of quantitative variables (protein C, protein $\mathrm{S}$, antithrombin III, DD, FDPs, CRP, hs-CRP, WBC count, procalcitonin) was evaluated using Kolmogorov-Smirnow $Z$ $(\mathrm{K}-\mathrm{S})$ test. Student's t-test was used to investigate differences with variables that showed normal distribution. Mann-Whitney $\mathrm{U}$ test was used for comparing two independent groups if the distributions were not a normal distribution. A " $p$ " value of less than 0.05 was considered statistically significant.

\section{Results}

One hundred and fifteen patients diagnosed with pneumonia ( $55.7 \%$ male and $44.3 \%$ female) were compared with the healthy control group of 87 children (57.5\% male and $42.5 \%$ female). The median age of study group was 36 months (2-216 months). The age distribution of the viral and bacterial pneumonia patient groups was similar [median age of the viral pneumonia group was 16.5 months (2-120 months) and median age of the bacterial pneumonia group was 17 months (2-168 months), $p=0.396$ ]. $26.9 \%$ of the patients $(n=31)$ were diagnosed with bacterial pneumonia while $73.1 \%(n=84)$ of them had viral pneumonia.

WBC numbers and DD levels in the pneumonia patients $\left(10.3 \pm 4.082 \times 10^{9} / \mathrm{L}\right.$ and $\left.0.47 \mu \mathrm{g} / \mathrm{mL}\right)$ were significantly higher compared to the control group $\left(8.116 \pm 2.876 \times 10^{9} / \mathrm{L}\right.$ and $0.18 \mu \mathrm{g} / \mathrm{mL} ; \mathrm{p}=0.001$ and 0.001 respectively as shown

Table I. Comparison of white blood cell numbers, anticoagulant proteins, and fibrinolytic system values between the patient and the control groups

\begin{tabular}{|c|c|c|c|}
\hline & $\begin{array}{l}\text { Patient group, } \\
(\mathrm{n}=115)\end{array}$ & $\begin{array}{l}\text { Healthy } \\
\text { control, }(n=87)\end{array}$ & $\begin{array}{l}\mathrm{p} \\
\text { value }\end{array}$ \\
\hline $\begin{array}{l}\text { White blood cell } \\
\text { count (/L) }\end{array}$ & $10.3 \pm 4.082$ & $8.116 \pm 2.876$ & $0.001^{*}$ \\
\hline $\begin{array}{l}\text { Antithrombin III } \\
\text { activity (\%) }\end{array}$ & $59.7 \pm 10.2$ & $84.6 \pm 10.3$ & $0.001^{*}$ \\
\hline $\begin{array}{l}\text { Protein C activity } \\
(\%)\end{array}$ & $67.6 \pm 17.1$ & $87.0 \pm 22.1$ & $0.001^{*}$ \\
\hline $\begin{array}{l}\text { Protein S activity } \\
(\%)\end{array}$ & $62.7 \pm 18.8$ & $61.0 \pm 24$ & $0.570^{*}$ \\
\hline D-dimer $(\mu \mathrm{g} / \mathrm{mL})$ & $0.47(0.06-2.80)$ & $0.18(0.01-3.78)$ & $0.001^{\dagger}$ \\
\hline $\begin{array}{l}\text { Fibrin } \\
\text { degradation } \\
\text { products }(\mu \mathrm{g} / \mathrm{mL})\end{array}$ & $3.8 \pm 2.8$ & $3.9 \pm 1.9$ & $0.482^{*}$ \\
\hline $\begin{array}{l}\text { Fibrin monomers } \\
(\mu \mathrm{g} / \mathrm{mL})\end{array}$ & $4.5(0.33-184)$ & $3.9(0.48-6)$ & $0.152^{\dagger}$ \\
\hline
\end{tabular}

${ }^{*}$ mean \pm standard deviation; ${ }^{\dagger}$ median (minimum-maximum) 
in Table I). At the same time, protein C activity in the pneumonia patients was lower compared to the control group $(67.6 \pm 17.1 \%$ and $87.0 \pm 22.1 \%$ respectively, $p=0.001)$. Antithrombin III activity was found to be lower in the patient group compared to that of the control group $(p=0.001)$. When protein $\mathrm{S}$ activity, FDPs, and fibrin monomers were evaluated, there was no significant difference between the patient group and the control group (Table I).

WBC count $\left(13 \pm 5.255 \times 10^{9} / \mathrm{L}\right.$ and $9.286 \pm 3.019 \times 10^{9} / \mathrm{L}$, $\mathrm{p}=0.001)$, CRP levels $(3.9 \mathrm{mg} / \mathrm{dL}$ and $0.4 \mathrm{mg} / \mathrm{dL}, \mathrm{p}=0.000)$, hs-CRP levels (10.6 mg/dL and $3.8 \mathrm{mg} / \mathrm{dL}, p=0.000)$, and procalcitonin levels $(0.13 \mathrm{mg} / \mathrm{dL}$ and $0.10 \mathrm{mg} / \mathrm{dL}, \mathrm{p}=0.014)$ were significantly higher in the bacterial pneumonia patients compared to the viral pneumonia patients (Table II). DD levels $(0.56 \mu \mathrm{g} / \mathrm{mL}$ and $0.044 \mu \mathrm{g} / \mathrm{mL}$ ) were also higher in the bacterial pneumonia patients $(p=0.046)$; however, other fibrinolytic marker FDPs and fibrin monomers were not significantly different (Table II). One of the natural anticoagulant proteins, protein S activity in the children with bacterial pneumonia (68.6 $\pm 20.8 \%$ ) was lower compared to the viral pneumonia patients $(60.5 \pm 17.7 \%, p=0.040)$, while there was no difference in terms of antithrombin III activity and protein $C$ activity (Table II).

Table II. Comparison of acute phase reactants, anticoagulant proteins, anticoagulant proteins, and fibrinolytic system markers between the bacterial and viral pneumonia patient groups

\begin{tabular}{|c|c|c|c|}
\hline & $\begin{array}{l}\text { Bacterial } \\
\text { pneumonia, } \\
(n=31)\end{array}$ & $\begin{array}{l}\text { Viral } \\
\text { pneumonia, } \\
(n=84)\end{array}$ & $p$ value \\
\hline $\begin{array}{l}\text { White blood cell } \\
\text { count (/L) }\end{array}$ & $13 \pm 5.255$ & $9.286 \pm 3.019$ & $0.001^{*}$ \\
\hline CRP (mg/dL) & $3.9(0.3-24)$ & $0.4(0.09-6)$ & $0.000^{+}$ \\
\hline hs-CRP (mg/dL) & $10.6(4.6-21)$ & $3.8(0.2-10.6)$ & $0.000^{+}$ \\
\hline $\begin{array}{l}\text { Procalcitonin } \\
\text { (mg/dL) }\end{array}$ & $0.13(0.06-7.02)$ & $0.10(0.02-2.23)$ & $0.014^{\dagger}$ \\
\hline $\begin{array}{l}\text { Antithrombin III } \\
\text { activity (\%) }\end{array}$ & $97.3 \pm 18.8$ & $103 \pm 13.4$ & $0.074^{*}$ \\
\hline $\begin{array}{l}\text { Protein C activity } \\
(\%)\end{array}$ & $66.9 \pm 18.1$ & $67.9 \pm 16.8$ & $0.782^{*}$ \\
\hline $\begin{array}{l}\text { Protein S activity } \\
(\%)\end{array}$ & $68.6 \pm 20.8$ & $60.5 \pm 17.7$ & $0.040^{*}$ \\
\hline D-dimer $(\mu \mathrm{g} / \mathrm{mL})$ & $0.56(0.12-2.80)$ & $0.044(0.06-1.95)$ & $0.046^{\dagger}$ \\
\hline $\begin{array}{l}\text { Fibrin } \\
\text { degradation } \\
\text { products ( } \mu \mathrm{g} / \\
\mathrm{mL} \text { ) }\end{array}$ & $4.9 \pm 2.7$ & $3.6 \pm 28$ & $0.150^{*}$ \\
\hline $\begin{array}{l}\text { Fibrin monomers } \\
(\mu \mathrm{g} / \mathrm{mL})\end{array}$ & $4.6(0.6-184)$ & $4.46(0.33-170)$ & $0.847^{\dagger}$ \\
\hline
\end{tabular}

${ }^{*}$ mean \pm standard deviation; ${ }^{\dagger}$ median (minimum-maximum)
A positive correlation was determined between DD and CRP ( $p=0.001 ; r=0.497) ; D D$ and hs-CRP ( $p=0.030$; $r=0.217)$, and $D D$ and procalcitonin $(p=0.026 ; r=0.208)$ in the pneumonia patients. At the same time, there was negative correlation between procalcitonin and protein $C$ $(p=0.044 ; r=-0.189)$; antithrombin III and CRP ( $p=0.018$; $r=-0.220)$, while antithrombin III and protein $C(p=0.001$; $r=0.417)$ and protein $C$ and protein $S(p=0.010 ; r=0.240)$ had positive correlation.

\section{Discussion}

Vascular congestion that develops in pneumonia cases may cause fibrin accumulation in alveoli. Recent studies support that intravascular and extravascular coagulation show a relationship with acute and chronic lung injury $(9,10)$. Enzymatic degradation of fibrin by the fibrinolytic system may cause FDPs, such as DD, to be released into the circulation $(8,9,11)$. Also, plasma DD levels may increase as a result of the activation of the blood coagulation process; which is caused by endotoxins in the gramnegative pathogens that trigger CAP (12). During pulmonary infections, the formation of fibrins could enhance host protection by containing infectious agents. Such protection may also be enhanced by protecting the endothelialepithelial barrier. On the other hand, coagulation as well as thrombin and fibrin products exhibit proinflammatory features that could negatively influence the reliability and function of the pulmonary system in severe acute respiratory distress syndrome (13).

In CAP patients, the relationship between coagulation activators and inhibitors and biomarkers is still not well known. In a study conducted with adults, DD was found to be high in heavy pneumonia cases while protein $C$ and antithrombin III were found to be low in CAP patients (8). Studies conducted with paediatric pneumonia cases are rare $(14,15)$. Långström et al. (14) found that in 28 CAP children with bacterial pneumonia, protein $C$ and antithrombin III were low while DD was significantly high.

Guo et al. (15) studied 52 children and found that lobar pneumonia and interstitial pneumonia patients had higher levels of thrombomodulin and DD levels compared to a control group. This suggests damage to the vascular endothelial cells and blood hypercoagulability may be involved in the pathogenesis of pneumonia.

In our study, protein $C$ and antithrombin III levels were found to be significantly low in CAP patients compared to the control group while the DD level was significantly high. At the same time, in bacterial pneumonia cases, the DD level was significantly high while the protein S level was low. Fibrin monomers and FDPs levels were higher in bacterial 
pneumonia cases, but the difference was not statistically significant.

Antithrombin III inhibits activated coagulation proteins by binding to them. Decreased antithrombin III levels are related to an elevated risk of thrombosis. It is reported that pulmonary vascular endothelium has a significant role in the catabolism of antithrombin III $(8,16)$. In heavy pneumonia cases, antithrombin III and protein C levels are found to be especially low (8). In our study, antithrombin III levels were found to be low in the pneumonia patients. Unlike other studies, this study found that protein S levels, a natural anticoagulant, were lower in the bacterial pneumonia cases. These findings suggest that natural anticoagulants have an important role in pneumonia pathogenesis.

The best laboratory procedure that shows coagulation activity is DD level analysis, which may elevate in acute coronary illness, deep vein thrombosis, peripheral vein diseases, pulmonary emboli, coronary failure, and DIC, which are situations in which fibrin formation and degradation increase. Studies show that DD levels increase in sepsis and pneumonia as well. Levi et al. (13) reported that DD levels in heavy pneumonia cases are not related to CRP and leucocyte numbers; however, they correlate with the existence of pleural liquid, the severity of pneumonia, and radiologic appearance. They also determined that DD levels are higher in alveolar or interstitial pneumonia patients compared to bronchopneumonia patients.

In studies conducted with adults, DD levels are reported to increase in bronchoalveolar lavage fluid of patients with pneumonia compared with controls, and DD levels increase progressively with severity, being higher in patients who require mechanical ventilation than in those with uncomplicated pneumonia (11). Other studies reported that DD levels in CAP patients are related to the severity of pneumonia, mortality, and morbidity (8,11,17-19).

In our study, DD levels were found to be high in pneumonia cases and they were higher in bacterial pneumonia cases than in viral pneumonia ones with a statistically significant difference. At the same time, the FDPs and fibrin monomer levels, which are important parameters of the fibrinolysis system, were higher in pneumonia patients. More research in this area needs to be done.

Pereira et al. (20) conducted their study with adults and reported that in severe CAP sepsis situations, high DD levels are important for an early diagnosis; DD, procalcitonin and CRP levels are correlated with each other. In the present study, DD levels in bacterial pneumonia patients were significantly higher and correlations among DD, FDPs and acute-phase proteins $C R P$, hs-CRP, and procalcitonin were observed.
Långström et al. (14) conducted their study on children with pneumonia and reported that, in bacterial pneumonia, DD and CRP are related. Other studies show that serum CRP concentration at the time of diagnosis correlates with the severity of CAP. Inflammatory response increases in pneumonia patients. Activated macrophages discharge inflammatory mediators such as interleukin- 6 which induces acute-phase proteins, like CRP (8). In this study, a positive correlation among DD and CRP, hs-CRP and procalcitonin levels in pneumonia patients was found; while a negative correlation between procalcitonin and protein C, and antithrombin III and CRP was observed.

\section{Study Limitations}

This study is limited to 115 patients presenting at the paediatric clinic of a major training and research hospital in Ankara, Turkey.

\section{Conclusion}

As a result, the relationships among acute phase proteins, anticoagulation proteins, and fibrinolytic system markers show that the coagulation and the fibrinolytic system has an important role in pneumonia pathogenesis and associated inflammation. Evaluation of the coagulation system may help determine the severity of pneumonia in children and be used to monitor its clinical progress. Further studies are needed on this subject.

\section{Ethics}

Ethics Committee Approval: The study was approved by the Ethics Committee of the Ankara Training and Research Hospital with file (approval number: 0533, date: 10.01.2014).

Informed Consent: All participants' parents provided written informed consent.

Peer-review: External and internal peer-reviewed.

\section{Authorship Contributions}

Surgical and Medical Practices: Z.Y., N.Ç., Concept: Z.Y., B.A., F.I.A., Design: Z.Y., B.A., F.I.A., Data Collection or Processing: N.Ç., Analysis or Interpretation: F.I.A, B.A., Literature Search: Z.Y., Writing: Z.Y., N.Ç.

Conflict of Interest: There is no conflict of interest to be reported by authors.

Financial Disclosure: No financial support was received for this study.

\section{References}

1. Kocabas E, Ersoz D, Karakoc F, et al. The diagnosis and treatment in children with pneumonia in the community reconciliation report. Turkish Thoracic ) 2009;10:1-26. 
2. Henrickson KJ. Viral pneumonia in children. Sem Pediatr Infect Dis ) 1998;9:217-33.

3. Ruuskanen O, Lahti E, Jennings LC, Murdoch DR. Viral pneumonia. Lancet 2011;377:1264-75

4. De Wals $P$, Robin E, Fortin E, Thibeault R, Ouakki $M$, Douville-Fradet M. Pneumonia after implementation of the pneumococcal conjugate vaccine program in the province of Quebec, Canada. Pediatr Infect Dis I 2008;27:963-8.

5. Nieuwenhuizen L, de Groot PG, Grutters IC, Biesma DH. A review of pulmonary coagulopathy in acute lung injury, acute respiratory distress syndrome, and pneumonia. Eur / Haematol 2009;82:413-25.

6. Petäjä J. Inflammation and coagulation. An overview. Thromb Res 2011;127:34-7.

7. Quick G, Eisenberg P. Bedside measurement of D-dimer in the identification of bacteremia in the emergency department. I Emerg Med 2000;19:217-23.

8. Agapakis DI, Tsantilas D, Psarris P, et al. Coagulation and inflammation biomarkers may help predict the severity of community-acquired pneumonia. Respirology 2010;15:796-803.

9. Abraham E. Coagulation abnormalities in acute lung injury and sepsis Am / Respir Cell Mol Biol 2000;22:401-4.

10. Günther A, Mosavi $P$, Heinemann $S$, et al. Alveolar fibrin formation caused by enhanced procoagulant and depressed fibrinolytic capacities in severe pneumonia. Comparison with the acute respiratory distress syndrome. Am J Respir Crit Care Med 2000;161:454-62.

11. Arslan S, Ugurlu S, Bulut G, Akkurt I. The association between plasma D-dimer levels and community-acquired pneumonia. Clinics 2010;65:593-7.
12. Bartlett JG, Dowell SF, Mandell LA, File TM Jr, Musher DM, Fine MJ. Practice guidelines for the management of communityacquired pneumonia in adults. Infectious Diseases Society of America. Clin Infect Dis 2000;31:347-82.

13. Levi M, Schultz MJ, Rijneveld AW, van der Poll T. Bronchoalveolar coagulation and fibrinolysis in endotoxemia and pneumonia. Crit Care Med 2003;31:238-42.

14. Långström S, Peltola $V$, Petäjä ), Ruuskanen $\mathrm{O}$, Heikinheimo $M$. Enhanced thrombin generation and depressed anticoagulant function in children with pneumonia. Acta Paediatr 2012;101:919-23.

15. Guo SC, Xu CW, Liu YQ, Wang JF, Zheng ZW. Changes in plasma levels of thrombomodulin and D-dimer in children with different types of Mycoplasma pneumoniae pneumonia. Zhongguo Dang Dai Er Ke Za Zhi 2013;15:619-22.

16. Proietta M, Pulignano I, Del Porto F, Tritapepe L, Di Giovanni C, Caronti B, Guglielmi R, Aliberti G. Antithrombin III metabolism in the pulmonary vessel endothelium. Blood Coagul Fibrinolysis 2007; 18:237-40

17. Chalmers JD1, Singanayagam A, Scally C, Hill AT. Admission D-dimer can identify low-risk patients with communityacquired pneumonia. Ann Emerg Med 2009;53:633-8.

18. Salluh II, Rabello LS, Rosolem MM, et al. The impact of coagulation parameters on the outcomes of patients with severe community-acquired pneumonia requiring intensive care unit admission. J Crit Care 2011;26:496-501.

19. Guneysel O, Pirmit S, Karakurt S. Plasma d-dimer levels increase with the severity of community acquired pneumonia. Tuberculosis and Thoracs Journal 2004;52:341-7.

20. Pereira JM, Paiva JA, Rello J. Severe sepsis in communityacquired pneumonia-early recognition and treatment. Eur / Intern Med 2012;23:412-9. 